\title{
Experimental Study on Four Cation Exchange Membranes in Electrosynthesis of Ammonium Persulfate
}

\author{
Chao Wang ${ }^{1}$, Junbo Zhou ${ }^{1 *}$, and Liping Gao ${ }^{2}$ \\ ${ }^{1}$ College of Mechanical and Electrical Engineering, Beijing University of Chemical Technology, No.15, Beisanhuan East \\ Road, Chaoyang District, Beijing, 100029, China \\ ${ }^{2}$ College of Biochemical Engineering, Beijing Union University, No. 18, FatouXili 3 Qu, Chaoyang District, Beijing, 100023, China
}

\begin{abstract}
In order to improve current efficiency and decrease energy consumption in the electrosynthesis of ammonium persulfate, electrolytic properties of four cation exchange membranes, namely, the JCM-II ${ }^{\mathbb{R}}$ membrane, Nafion ${ }^{\mathbb{R}} 324$ membrane CMI$7000^{\mathbb{B}}$ membrane and a self-made perfluorosulfonic ion exchange membrane (PGN membrane) were investigated using a sintered platinized titanium anode and a Pb-Sb-Sn alloy cathode in a self-made electrolytic cell. The effect of cell voltage and electrolyte flow rate on the current efficiency and the energy consumption were investigated. The results indicated that the PGN membrane could improve current efficiency to $94.85 \%$ and decrease energy consumption to $1119 \mathrm{kWh} \mathrm{t}^{-1}$ (energy consumption per ton of the ammonium persulfate generated) under the optimal operating conditions and the highest current efficiency of the JCM-II ${ }^{\circledR}$ membrane, Nafion ${ }^{\circledR} 324$ membrane and CMI-7000 ${ }^{\circledR}$ membrane were $80.73 \%, 77.76 \%$ and $73.22 \%$ with their lowest energy consumption of $1323 \mathrm{kWh} \mathrm{t}^{-1}, 1539 \mathrm{kWh} \mathrm{t}^{-1}$ and $2256 \mathrm{kWh} \mathrm{t}^{-1}$, respectively. The PGN membrane has the advantages of high current efficiency and energy power consumption and has sufficient mechanical strength with the reinforced mesh. Therefore the PGN membrane will has good value in popularization in the industrial electrosynthesis of ammonium persulfate in the future.
\end{abstract}

Keywords : Electrosynthesis, Ammonium persulfate, Current efficiency, Energy consumption, PGN membrane

Received : 22 November 2017, Accepted : 31 January 2018

\section{Introduction}

Ammonium persulfate $\left(\left(\mathrm{NH}_{4}\right)_{2} \mathrm{~S}_{2} \mathrm{O}_{8}\right)$ exhibiting strong oxidizing property is widely used as an initiator agent in the organic synthesis industries, as oxidizing and bleaching agents in the wastewater treatment, detergents, electronics and chemical industries [1-2]. Ammonium persulfate is mainly manufactured electrochemically via ion exchange membrane electrolysis of ammonium sulfate at the industrial scale [3]:

\section{Anode reaction:}

$$
\begin{aligned}
& \text { Anode reaction: } \\
& 2 \mathrm{SO}_{4}^{2-} \rightarrow \mathrm{S}_{2} \mathrm{O}_{8}^{2-}+2 e \quad E^{0}=2.01 \mathrm{~V}(\mathrm{SHE})
\end{aligned}
$$

*E-mail address: wangchaobuct@163.com

DOI: https://doi.org/10.5229/JECST.2018.9.1.37
Cathode reaction:

$$
2 H^{+}+2 e^{-} \rightarrow H_{2} \quad E^{0}=0 \mathrm{~V}(\mathrm{SHE})
$$

The mainly competing oxygen reaction:

$$
2 \mathrm{H}_{2} \mathrm{O} \rightarrow 4 \mathrm{H}^{+}+\mathrm{O}_{2} \uparrow+4 \mathrm{e}^{-} \quad E^{0}=0 \mathrm{~V}(\mathrm{SHE})
$$

SHE: standard hydrogen electrode.

Nowadays, improving current efficiency and decreasing energy consumption of the electrosynthesis of ammonium persulfate are important research aspects mainly involving anode materials, cathode materials, additives and ion exchange membranes [47]. Pt electrode is excellent catalysts in many electrochemical reactions [8] and it is valuable to research the sintered platinized titanium anode with much lower cost. Over the past decades, ion exchange 
membranes have found large-scale application in processes such as electrodialysis, electrodeionization, and persulfuric acid production [9-12]. At present, the application and the development of new ion exchange membranes and the commercial ion exchange membranes in different fields are important aspects of research [13].

In recent years, ion exchange membranes have played a significant role in improving current efficiency and decreasing energy consumption of the electrosynthesis of ammonium persulfate [14]. The ion exchange membranes widely researched usually involve the membranes widely-used in chemical industries such as Nafion ${ }^{\circledR} 424$ [15-16] and Nafion ${ }^{\circledR}$ 117 [17], newly developed membranes and other commercial ion exchange membranes [18].

H. Nan et al. [18] developed several novel composite membranes that were applied to the research of the electrosynthesis of ammonium persulfate in the laboratory and improved current efficiency to $76.3 \%$ and decreased the energy consumption to $1485 \mathrm{kWh} \mathrm{t}^{-1}$ (energy consumption per ton of the ammonium persulfate generated) using a titanium anode with platinum welded and $\mathrm{a} \mathrm{Pb-Sb}$ alloy cathode, the energy consumption of which was still high. Y. Cong et al. [19] improved current efficiency to $72.4 \%$ and decreased the energy consumption to $1485 \mathrm{kWh} \mathrm{t}^{-1}$ at an electrolytic cell voltage of $5.29 \mathrm{~V}$ using a polytetrafluoroethylene cation exchange membrane on a platinum anode and a lead cathode but the mechanical strength of the polytetrafluoroethylene was weak so that it was not easy to install in an electrolytic cell and it had a low ability to resist the bubble impact during the electrolysis.

Therefore the application and the development of new ion exchange membranes should not only reduce the energy consumption but should also have a sufficient mechanical strength. In this paper, The PGN membrane in the experiments was the perfluorosul- fonic ion exchange membrane made by solution coasting technology combined with polytetrafluoroethylene reinforced mesh. The experiments were carried out to research the properties of the PGN membrane, JCM-II ${ }^{\circledR}$ membrane, Nafion ${ }^{\circledR} 324$ membrane and CMI-7000 ${ }^{\circledR}$ membrane in the electrolysis process to find out the membranes that could be efficient to improve the current efficiency and decrease the energy consumption in the electrosynthesis of ammonium persulfate.

\section{Experimental}

\subsection{Materials and chemicals}

Sulfuric acid $\left(\mathrm{H}_{2} \mathrm{SO}_{4}\right)$, ammonium sulfate $\left(\left(\mathrm{NH}_{4}\right)_{2} \mathrm{SO}_{4}\right)$, ammonium persulfate $\left(\left(\mathrm{NH}_{4}\right)_{2} \mathrm{~S}_{2} \mathrm{O}_{8}\right)$ and other chemicals for volumetric titration analysis (ferrous sulfate $\left(\mathrm{FeSO}_{4}\right)$ and potassium permanganate $\left.\left(\mathrm{KMnO}_{4}\right)\right)$ used were of analytical grade and purchased from Weisi (Beijing) Experimental Supplies Co., Ltd. The PGN membrane is a self-made perfluorosulfonic ion exchange membrane. The JCM-II ${ }^{\circledR}$ membrane, Nafion ${ }^{\circledR} 324$ membrane and CMI- $7000^{\circledR}$ membrane were purchased from Beijing Tingrun Membrane Technology Development Co., Ltd, Changzhou City Jianhui Trade and Business Co., Ltd and RingSun Membrane Technology (Beijing) Co., Ltd, respectively.

The PGN membrane is made by solution coasting technology combined with polytetrafluoroethylene reinforced mesh with the equivalent weight of 0.8 $\left(\mathrm{mmol} \mathrm{g}^{-1}\right)$, the water content of $20 \%$ at $25^{\circ} \mathrm{C}$ and the density of $2.1 \mathrm{~g} \mathrm{~cm}^{-3}$ with the proper $\mathrm{pH}$ ranging from 1 to 14 . And the physical properties of the four membranes are shown in Table 1.

From the Table 1, it can be seen that the thickness of CMI-7000 membrane is the highest with the lowest ionic conductivity. And the ion exchange capacity of JCM-II membrane is the highest with the highest

Table 1. The physical properties of the four membranes.

\begin{tabular}{|c|c|c|c|c|c|c|}
\hline Membrane & $\begin{array}{c}\text { Thickness } \\
(\mu \mathrm{m})\end{array}$ & $\begin{array}{c}\text { Ionic } \\
\text { conductivity } \\
(\mathrm{S} / \mathrm{cm})\end{array}$ & $\begin{array}{l}\text { Burst strength } \\
\quad(\mathrm{MPa})\end{array}$ & $\begin{array}{c}\text { Ion exchange } \\
\text { capacity } \\
\text { (meq/g) }\end{array}$ & $\begin{array}{c}\text { Thermal } \\
\text { stability range } \\
\left({ }^{\circ} \mathrm{C}\right)\end{array}$ & $\begin{array}{c}\text { Water } \\
\text { Content } \\
(\%)\end{array}$ \\
\hline PGN & 320 & 0.12 & 0.5 & 1.3 & $5-80$ & 33 \\
\hline JCM-II & 200 & 0.13 & 0.25 & 2 & $5-70$ & 38 \\
\hline Nafion 324 & 175 & 0.11 & 0.52 & 0.92 & $5-90$ & 31 \\
\hline CMI-7000 & 450 & 0.087 & 0.55 & 1.0 & $5-90$ & 20 \\
\hline
\end{tabular}




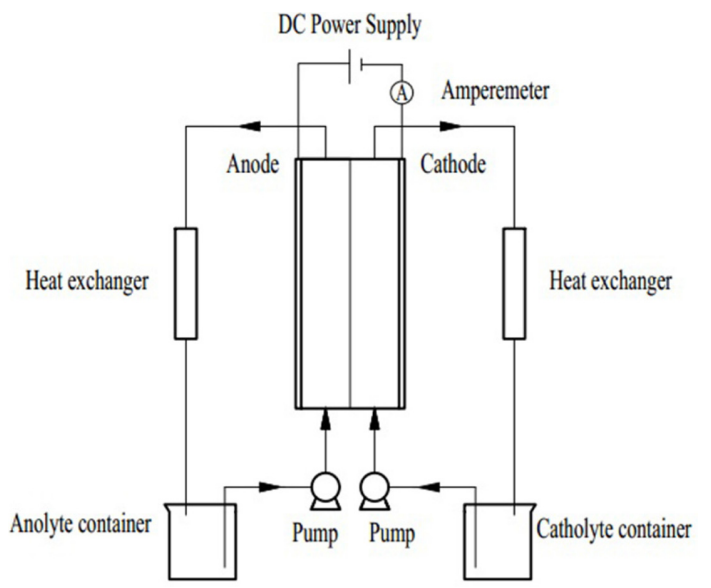

Fig. 1. Diagram of the experimental apparatus.

ionic conductivity and the thermal stability ranges of the four membranes are appropriate for the temperature required by the electrosynthesis of ammonium persulfate ranging from $25^{\circ} \mathrm{C}$ to $45^{\circ} \mathrm{C}$. Besides the functional group of the four membranes is sulphonic acid. Besides, the JCM-II membrane is the only one without reinforced mesh.

\subsection{Experimental apparatus}

The diagram of the experimental apparatus for the electrolysis of ammonium persulfate is shown in Fig. 1 that consists of a self-made frame-and-plate cell for performing the reaction, a sintered platinized titanium anode from Baoji Hengrui Titanium Anode and Titanium Product Co., Ltd, a Pb-Sb-Sn alloy cathode from Shanghai Huiyan Welding Material Co., Ltd, a DC power supply (YB1721A) from Shanghai Huyue Electric Technology Co., Ltd, two peristaltic pumps (TP12DC24V) from Guangzhou Jiyou Plastic Pipe Fittings Technology Co., Ltd for circulating anolyte and catholyte, respectively, two self-made heat exchangers for maintaining the temperature of electrolytes, a DC ammeter (DP3-72A) from Zhejiang Taiquan Electrical Appliances Co., Ltd. The electrode dimensions are $40 \mathrm{~mm} \times 60 \mathrm{~mm} \times 2 \mathrm{~mm}$, the interelectrode gap of which is about $6 \mathrm{~mm}$ with two silicone gaskets having an effective electrolytic area of $7 \mathrm{~cm}^{2}$ between the membrane and the electrodes.

\subsection{Experimental design}

All experiments were conducted using constant voltage method with the electrolytes continually pumped between the electrolytic cell and the corresponding electrolyte container. The reaction was operated in batch recycle mode. The electrochemical reaction in the electrolytic cell was operated for 30 min using $100 \mathrm{~mL}$ initial anolyte with a mixture of $90 \mathrm{~g} \mathrm{~L}^{-1}\left(\mathrm{NH}_{4}\right)_{2} \mathrm{~S}_{2} \mathrm{O}_{8}$ and $460 \mathrm{~g} \mathrm{~L}^{-1}\left(\mathrm{NH}_{4}\right)_{2} \mathrm{SO}_{4}$ and $100 \mathrm{~mL}$ initial catholyte with a mixture of $49 \mathrm{~g} \mathrm{~L}^{-1}$ $\mathrm{H}_{2} \mathrm{SO}_{4}$ and $400 \mathrm{~g} \mathrm{~L}^{-1}\left(\mathrm{NH}_{4}\right)_{2} \mathrm{SO}_{4}$ at the temperature ranging from $30^{\circ} \mathrm{C}$ to $35^{\circ} \mathrm{C}$ and the electrolyte flow rate ranging from $20 \mathrm{~mL} \mathrm{~min}^{-1}$ to $70 \mathrm{~mL} \mathrm{~min}^{-1}$, the temperature and composition of which were the same as those in the industrial production of ammonium persulfate. The initial experiments were performed at the cell voltage of $4.5 \mathrm{~V}$ for $30 \mathrm{~min}$ with the electrolytes recirculating through the electrolysis cell at the electrolyte flow of $60 \mathrm{~mL} \mathrm{~min}{ }^{-1}$. Samples were extracted at the anolyte outlet for analysis when each experiment was finished.

\subsection{Analytical methods}

The amount of the ammonium persulfate generated was determined using the potassium permanganate method. Samples of solutions were treated by excess $0.2 \mathrm{~mol} \mathrm{~L}^{-1}$ standard $\mathrm{FeSO}_{4}$ solution, which generated $\mathrm{Fe}_{2}\left(\mathrm{SO}_{4}\right)_{3}$ with surplus $\mathrm{FeSO}_{4}$. The surplus $\mathrm{FeSO}_{4}$ was measured using $0.01 \mathrm{~mol} \mathrm{~L}^{-1}$ standard $\mathrm{KMnO}_{4}$ solution that could be used as an indicator to determine the end point of the titration.

The concentration of the ammonium persulfate (c, mol L ${ }^{-1}$ ) was calculated using Eqn. (1):

$$
C=\frac{\left(c_{1} V_{1}-5 c_{2} V_{2}\right)}{n V}
$$

where $c_{1}$ and $c_{2}$ are the concentration of the $\mathrm{FeSO}_{4}$ solution and the $\mathrm{KMnO}_{4}$ solution, respectively, mol $\mathrm{L}^{-1} ; \mathrm{V}, \mathrm{V}_{1}$ and $\mathrm{V}_{2}$ are the titration volume of samples, $\mathrm{FeSO}_{4}$ solution and $\mathrm{KMnO}_{4}$ solution, respectively, L; $\mathrm{n}$ is the number of electrons involved in the electrode reaction.

The experimental current efficiency $(\eta, \%)$ was calculated using Eqn. (2):

$$
\eta=\frac{n F V_{0}\left(c_{4}-c_{3}\right)}{I t} \times 100 \%
$$

where $c_{3}$ and $c_{4}$ are the concentration of ammonium persulfate before electrolysis and after electrolysis, respectively, mol L-1 $; \mathrm{V}_{0}$ is the total volume of the anolyte, L; I is the working current, A; $t$ is the total time of the constant cell voltage applied, s; F is the 


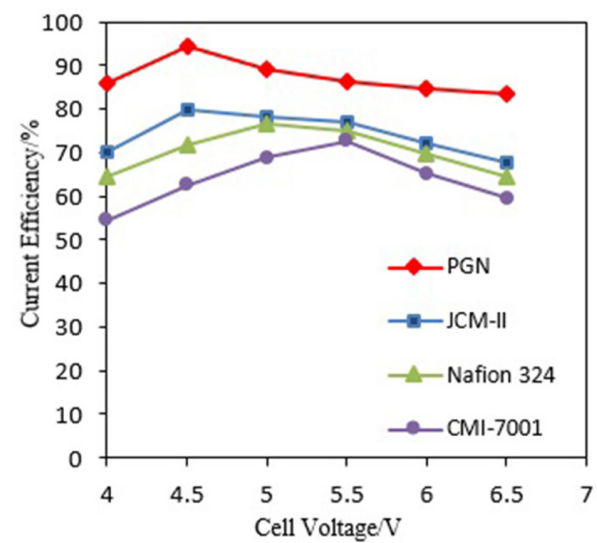

Fig. 2. Current efficiency of the four membranes at different cell voltage at the electrolyte flow rate of $60 \mathrm{~mL}$ $\min ^{-1}$.

Faraday constant, $96485 \mathrm{C} \mathrm{mol}^{-1}$.

The experimental energy consumption per ton of the ammonium persulfate generated $\left(\mathrm{W}, \mathrm{kWh} \mathrm{t}^{-1}\right)$ is calculated using Eqn. (3):

$$
W=\frac{U I t / 3600 / 1000}{V_{0}\left(c_{4}-c_{3}\right) M / 10^{6}}=\frac{U I t}{3.6 V_{0}\left(c_{4}-c_{3}\right) M}=\frac{n F U}{3.6 M \eta}
$$

where $\mathrm{U}$ is the constant cell voltage applied, $\mathrm{V} ; \mathrm{M}$ is the molar mass of ammonium persulfate, $\mathrm{g} \mathrm{mol}^{-1}$.

\section{Results and Discussion}

\subsection{The effect of cell voltage on current efficiency and energy consumption}

Fig. 2 shows the effect of cell voltage on the current efficiency of the PGN membrane, JCM-II ${ }^{\circledR}$ membrane, Nafion ${ }^{\circledR} 324$ membrane and CMI- $7000^{\circledR}$ membrane at an electrolyte flow rate of $60 \mathrm{~mL} \mathrm{~min}^{-1}$. The current efficiency of the PGN membrane, JCMII ${ }^{\circledR}$ membrane, Nafion ${ }^{\circledR} 324$ membrane and CMI$7000^{\circledR}$ membrane reached their maximum values, $94.35 \%, 79.94 \%, 76.82 \%$ and $72.74 \%$ at the cell voltage of $4.5 \mathrm{~V}, 4.5 \mathrm{~V}, 5 \mathrm{~V}$ and $5.5 \mathrm{~V}$, respectively, which resulted from the promoted anode reaction producing ammonium persulfate and the inhibited oxygen evolution reaction with current density increasing and the other operating conditions unchanged. When cell voltage exceeded their optimal values, the current efficiency of the PGN membrane, JCM-II ${ }^{\circledR}$ membrane, Nafion ${ }^{\circledR} 324$ membrane and CMI $-7000^{\circledR}$ membrane gradually declined with cell

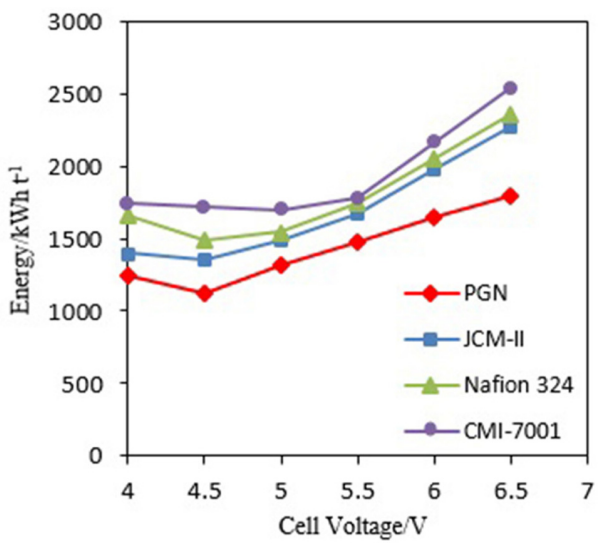

Fig. 3. Energy consumption of the four membranes at different cell voltage at the electrolyte flow rate of $60 \mathrm{~mL}$ $\min ^{-1}$

voltage increasing, which was attributed to the enhanced oxygen evolution reaction caused by the increased anode potential when cell voltage increased.

From Table 1 and Fig. 2, It could been seen that the cell voltage corresponding to the highest current efficiency of the four membranes almost increased with their ionic conductivity increasing because the higher the ionic conductivity of the membrane, the higher the membrane voltage loss when the other conditions were the same.

As was shown in Fig. 3, the energy consumption of the PGN membrane, JCM-II ${ }^{\circledR}$ membrane, Nafion ${ }^{\circledR}$ 324 membrane and CMI- $7000^{\circledR}$ membrane reached their minimum values, $1120 \mathrm{kWh} \mathrm{t}^{-1}, 1357 \mathrm{kWh} \mathrm{t}^{-1}$, $1493 \mathrm{kWh} \mathrm{t}^{-1}$ and $1702 \mathrm{kWh} \mathrm{t}^{-1}$ at the cell voltage of $4.5 \mathrm{~V}, 4.5 \mathrm{~V}, 5 \mathrm{~V}$ and $5.5 \mathrm{~V}$, respectively. As was shown in Fig. 2 and Fig. 3, the current efficiency of the PGN membrane was highest among the four membranes with the lowest energy consumption. With respect to the four membranes at the same cell voltage, the higher the current efficiency was, the lower energy consumption was, which corresponded with Eqn. (3).

Although the ionic conductivity of JCM-II ${ }^{\circledR}$ membrane was the highest among the four membranes, its ion exchange capacity was much higher than that of the other membranes resulting in the decline of its selective permeability, which reduced its current efficiency and increased its energy consumption. Besides, because of the weak mechanical strength of 
the JCM-II ${ }^{\circledR}$ membrane, it was not easy to install in an electrolytic cell and it had a low ability to resist the pressure and bubble impact during the electrolysis. With regard to the Nafion ${ }^{\circledR} 324$ membrane, although its ionic conductivity was almost equal to that of the PGN membrane, its ion exchange capacity was much lower than that of the PGN membrane causing its lower current efficiency and higher energy consumption than those of the PGN membrane. As for the CMI-7000 ${ }^{\circledR}$ membrane with the lowest ionic conductivity, its membrane voltage loss was the highest, which contributed to its lowest current efficiency and its highest energy consumption under the same cell voltage compared with the other three membranes. With respect to the PGN membrane, its proper ion exchange capacity made its selective permeability good and its ionic conductivity made its membrane loss lower at the cell voltage than those of the CMI-7000 ${ }^{\circledR}$ membrane and the Nafion ${ }^{\circledR} 324$ membrane, which contributed to its highest current efficiency and its lowest energy consumption compared with the other three membranes.

\subsection{The effect of electrolyte flow rate on current efficiency and energy consumption}

Fig. 4 shows the current efficiency of the PGN membrane, JCM-II ${ }^{\circledR}$ membrane, Nafion ${ }^{\circledR} 324$ membrane and CMI- $7000^{\circledR}$ membrane as a function of electrolyte flow rate at the cell voltage of $4.5 \mathrm{~V}, 4.5 \mathrm{~V}$, $5 \mathrm{~V}$ and $5.5 \mathrm{~V}$, respectively. The current efficiency of the PGN membrane, JCM-II ${ }^{\circledR}$ membrane, Nafion ${ }^{\circledR}$ 324 membrane and CMI- $7000^{\circledR}$ membrane increased with the electrolyte flow rate increasing and reached their maximum values, $94.85 \%, 80.73 \%, 77.76 \%$ and $73.22 \%$, respectively, at the electrolyte flow of $70 \mathrm{~mL} \mathrm{~min}^{-1}$ and there was no significant increase in the current efficiency of the four membranes at the electrolyte flow rate from $60 \mathrm{~mL} \mathrm{~min}^{-1}$ to $70 \mathrm{~mL} \mathrm{~min}^{-1}$ suggesting that the mass transfer was not the reaction rate determining step at the electrolyte flow rate between $60 \mathrm{~mL} \mathrm{~min}^{-1}$ and $70 \mathrm{~mL} \mathrm{~min}^{-1}$ in the present system apparatus [15].

Fig. 5 shows that the energy consumption of the PGN membrane, JCM-II ${ }^{\circledR}$ membrane, Nafion ${ }^{\circledR} 324$ membrane and CMI-7000 ${ }^{\circledR}$ membrane reached their minimum values, $1323 \mathrm{kWh} \mathrm{t}^{-1}, 1770 \mathrm{kWh} \mathrm{t}^{-1}$ and $2256 \mathrm{kWh} \mathrm{t}^{-1}$ at the cell voltage of $4.5 \mathrm{~V}, 4.5 \mathrm{~V}, 5 \mathrm{~V}$ and $5.5 \mathrm{~V}$, respectively, at the electrolyte flow of $70 \mathrm{~mL} \mathrm{m^{-1 }}$. As was shown in Fig. 4 and Fig. 5, the

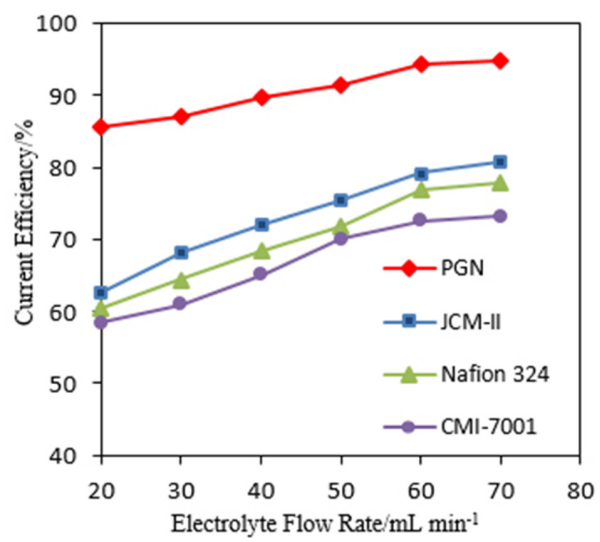

Fig. 4. Current efficiency of the four membranes at different electrolyte flow rate, PGN membrane, JCM-II membrane, Nafion 324 membrane and CMI-7000 membrane at the cell voltage of $4.5 \mathrm{~V}, 4.5 \mathrm{~V}, 5 \mathrm{~V}$ and $5.5 \mathrm{~V}$, respectively.

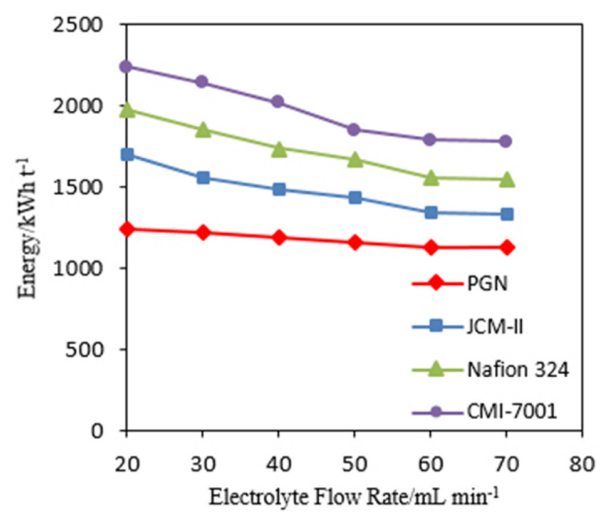

Fig. 5. Energy consumption of the four membranes at different electrolyte flow rate, PGN membrane, JCM-II membrane, Nafion 324 membrane and CMI-7000 membrane at the cell voltage of $4.5 \mathrm{~V}, 4.5 \mathrm{~V}, 5 \mathrm{~V}$ and $5.5 \mathrm{~V}$, respectively.

current efficiency of the PGN membrane was highest with the lowest energy consumption among the four membranes.

Y. Wang zet al. [17] improved the current efficiency to $84.13 \%$ adopting a Nafion 117 membrane with ammonium polyphosphate as the anode additive in the electrosynthesis of ammonium persulfate. But the Nafion ${ }^{\circledR} 117$ membrane was not easy to install in an electrolytic cell because of its low mechanical strength without reinforced mesh. J. Zhao et al. [15] improved the current efficiency to $80 \%$ using a 
Nafion ${ }^{\circledR} 427$ membrane but the energy consumption reached $2000 \mathrm{kWh} \mathrm{t}^{-1}$ due to the low electrolyte conductivity caused by the low reaction temperature of $15^{\circ} \mathrm{C}$. Besides, the low electrolyte temperature would reduce the solubility of ammonium persulfate, which would reduce the electrosynthesis rate of ammonium persulfate.

J. Zhu et al. [15] used the Nafion 424 cation exchange membrane, with a mixture of $456 \mathrm{~g} \mathrm{~L}^{-1}$ $\left(\mathrm{NH}_{4}\right)_{2} \mathrm{SO}_{4}$ in $196 \mathrm{~g} \mathrm{~L}^{-1} \mathrm{H}_{2} \mathrm{SO}_{4}$ as electrolytes, improved current efficiency to $93 \%$ in the electrosynthesis of ammonium persulfate at the temperature less than $15^{\circ} \mathrm{C}$, whereas the strong electrolyte acid made ammonium persulfate easy to decompose [20] and required electrolysis equipments with high corrosion resistance. With regard to the composite membrane of perfluorosulfonic acid and perfluorocarboxylic acid, the carboxylic salt layer turns into carboxylic acid layer when the $\mathrm{pH}$ of the anolyte is less than 2 in the electrosynthesis of ammonium persulfate, which results in serious reduction of conductive performance, the increase of the cell voltage, even blisters of the membrane and holes of the perfluorocarboxylic acid layer.

In addition, with the increase of the ion exchange capacity of the membranes, their water content increases, which can increase the possibility of coions percolation through the membranes decreasing the selective permeability of the membranes [21-22]. As can be seen from the Table 1, with respect to the four membranes, although the ionic conductivity of the JCM-II ${ }^{\circledR}$ membrane is the highest, its high water content restricts the improvement of its current efficiency. Compared with the PGN membrane, although the water content of the CMI-7000 ${ }^{\circledR}$ membrane and the Nafion ${ }^{\circledR} 324$ membrane is lower, their ion exchange capacity and ionic conductivity are much lower than those of the PGN membrane, which increases their energy consumption in the electrosynthesis of ammonium persulfate. Therefore, the proper ion exchange capacity, ionic conductivity and water content enable the PGN membrane to have high current efficiency and low energy consumption in the electrosynthesis of ammonium persulfate.

The temperature of the experiments was maintained from $30^{\circ} \mathrm{C}$ to $35^{\circ} \mathrm{C}$, which not only prevented the ammonium persulfate from decomposing but also increased the electrolyte conductivity and the solubility of ammonium persulfate, which could increase the current efficiency and reduce the energy consumption of the membranes. The PGN membrane has high current efficiency and low energy consumption with high mechanical strength. With respect to the JCM-II ${ }^{\mathbb{R}}$ membrane with lower mechanical strength, further research can be continued in the electrosynthesis of ammonium persulfate when it is enhanced by reinforced mesh.

\section{Conclusions}

This research indicates that the current efficiency of the PGN membrane is highest and its energy consumption is lowest compared with the JCM-II ${ }^{\mathbb{R}}$ membrane, the Nafion ${ }^{\circledR} 324$ membrane and the CMI$7000^{\circledR}$ membrane with $100 \mathrm{~mL}$ mixture of $90 \mathrm{~g} \mathrm{~L}^{-1}$ $\left(\mathrm{NH}_{4}\right)_{2} \mathrm{~S}_{2} \mathrm{O}_{8}$ and $460 \mathrm{~g} \mathrm{~L}^{-1}\left(\mathrm{NH}_{4}\right)_{2} \mathrm{SO}_{4}$ as anolyte and $100 \mathrm{~mL}$ mixture of $49 \mathrm{~g} \mathrm{~L}^{-1} \mathrm{H}_{2} \mathrm{SO}_{4}$ and $400 \mathrm{~g} \mathrm{~L}^{-1}$ $\left(\mathrm{NH}_{4}\right)_{2} \mathrm{SO}_{4}$ at as catholyte at the electrolyte flow rate ranging from $20 \mathrm{~mL} \mathrm{~min}^{-1}$ to $70 \mathrm{~mL} \mathrm{~min}^{-1}$ and the temperature ranging from $30^{\circ} \mathrm{C}$ to $35^{\circ} \mathrm{C}$ in the electrosynthesis of ammonium persulfate. With its proper ion exchange capacity and the ionc conductivity of $0.12 \mathrm{~S} / \mathrm{cm}$, the current efficiency of the PGN membrane can reach $94.85 \%$ with energy consumption of $1119 \mathrm{kWh} \mathrm{t}^{-1}$ at the cell voltage of $4.5 \mathrm{~V}$ at the temperature ranging from $30^{\circ} \mathrm{C}$ to $35^{\circ} \mathrm{C}$ and an electrolyte flow rate of $70 \mathrm{~mL} \mathrm{~min}^{-1}$. In addition, the PGN membrane has good mechanical strength with reinforced mesh. Therefore we believe that the PGN membrane will have a good application prospect in the industrial practice of electrosynthesis of ammonium persulfate.

\section{References}

[1] L.R. Bennedsen, In situ chemical oxidation: The Mechanisms and Applications of Chemical Oxidants for Remediation Purposes, Elsevier B.V., Amsterdam, 2014.

[2] H. Jakob, S. Leininger, T. Lehmann, et al., Peroxo Compounds, Inorganic. Ullmann's Encyclopedia of Industrial Chemistry, Wiley-VCH, Weinheim, 2007.

[3] N. Xu, Guangdong Chem. Ind. (Natural Science Edition), 2015, 42, 114-114.

[4] K.K. Hii, K.Hellgardt, G.H.Kelsall, et al, Apparatus and method for production of oxidants, WO/2016/ 193738A1.

[5] V.B. Martos, E. Herrero, J.M. Feliu, Electrochim. Acta, 2017, 241, 497-509.

[6] J.R. Davis, J.C. Baygents, J.Farrell, J. Appl. Electrochem., 2014, 44(7), 841-848. 
[7] J.R. Davis, J.C. Baygents, J.Farrell, Electrochim. Acta, 2014, 150, 68-74.

[8] G. Dutta, H. Yang, J. Electrochem. Sci. Technol., 2016, 7(1), 27-32.

[9] J. Ran, L. Wu, Y.B. He, et al, J. Membr. Sci, 2017, 522, 267-291.

[10] E. Bakangura, C. Cheng, L. Wu, et al., J. Membr. Sci, 2017, 537, 32-41.

[11] G.A. Crespo, Electrochim. Acta, 2017, 245, 1023 -1034.

[12] S. Paul, J. Electrochem. Sci. Technol, 2016, 7(2), 115131.

[13] R.S.L. Yee, R.A. Rozendal, K. Zhang, et al., Chem. Eng Res. Des., 2012, 90(7), 950-959.

[14] H. Strathmann, A.Grabowski, G.Eigenberger, Ind. Eng. Chem. Res, 2013, 52(31), 10364-10379.
[15] J. Zhu, K.K. Hii, K. Hellgardt, Acs Sustain. Chem. Eng, 2016, 4(4), 2027-2036.

[16] J. Zhao, P. Sun, L. Wang, et al., J. Zhengzhou Univ. (Engineering. Science), 2006, 27, 109-112.

[17] Y. Wang, Y. Xiong, J. Zhang, J. Southeast Univ., 2015, 45, 738-744.

[18] H. Nan, Y. Wang, Chem. Ind. Eng., 2013, 30, 53-58.

[19] CONG, Yu-feng, et al., J. Fushun Petroleum Ins., 2001, 21, 23-31.

[20] R.L. Johnson, P.G. Tratnyek, R.O. Johnson, Environ. Sci. Technol, 2008, 42(24), 9350-9356.

[21] M. Nemati, S.M. Hosseini, M. Shabanianb, J. Hazard. Mater., 2017, 337, 90-104.

[22] S.M. Hosseini, M. Nemati, F. Jeddi, et al., Desalination, 2015, 359, 167-175. 